\title{
О. О. ТИЩЕНКО-МОНАСТИРСЬКА
}

Інститут мовознавства ім. О.О. Потебні НАН України

м. Київ, Україна

Електронна пошта: tyshchenko.monastyrska@gmail.com https://orcid.org/0000-0001-8515-1657

\section{ОРФОГРАФІЧНІ ОСОБЛИВОСТІ КРИМЧАЦЬКОГО РУКОПИСУ ДЖОНК ТА ПИСЕМНА ТРАДИЦІЯ КРИМЧАКІВ}

Стаття присвячена аналізові орфографічних особливостей кримчацького рукопису «Джонк Йосифа Габая» з Кримського етнографічного музею (м. Сімферополь). Фрагменти рукопису були вперше транслітеровані, перекладені російською мовою та опубліковані Давидом Ребі, учителем кримчацької мови та її носієм (Реби 2010). Однак предметом наукового аналізу цей матеріал досі ще не був. Особлива цінність пам'ятки полягає в її мові (навіть мовах) та розмаїтті стилів. Цей рукопис був створений у Феодосії в першій половині XX ст. Пам'ятка - багатомовна, містить фольклорні тексти (народну поезію та прозові твори) кримського, турецького походження, написані гебрайським письмом, щоденні нотатки кримчацькою та російською мовами, молитви і релігійні тексти гебрайською мовою та в перекладі кримчацьким ідіомом. Писемна традиція кримчаків попри використання гебрайської абетки розвинулася в тісному зв'язку з дореформеною кримськотатарською писемною традицією, обидва писемних варіанти своєю чергою мають чимало спільних рис зі староосманською (раннього періоду) та доосманською писемними традиціями. На це вказують численні орфографічні особливості, зокрема принципи графічного оформлення, способи написання голосних, приголосних у різних позиціях слова (початок, середина, кінець слова), словотворчих та формотворчих суфіксів (разом чи окремо), відображення морфонологічних змін засобами консонантного письма, засоби відтворення та адаптації запозичень. Мова рукопису джонка Йосифа Габая відображає орфографічні та розмовні особливості, властиві кримчацькому етнолектові та демонструє спільні риси з іншими тюркськими писемними пам’ятками Криму цього періоду.

Ключові слова: кримчацька мова, гебрайсько-тюркська орфографія, відокремлена суфіксація.

Кримчацька мова є однією з корінних тюркських мов Криму, що нині перебуває на межі зникнення та під захистом Свропейської хартії регіональних мов або мов меншин. Носіями кримчацької мови є кримські юдеї,

1 Статтю підготовлено в рамках наукового проєкту програми мобільності JESH (Joint Excellence in Science and Humanities) Австрійської академії наук за підтримки Федерального міністерства освіти, науки і досліджень Республіки Австрія.

(c) О. О. ТИЩЕНКО-МОНАСТИРСЬКА, 2020 
Güllüdağ N. (2014). Kırımçak Türkçesi Grameri. Ankara: Gece Kitaplığı.

Ianbay I. (2001). Tyurkskaya literatura krymčakov. Materialy po arkheologii, istorii i etnografii Tavrii. Vol. 7. Kerch [b.v.], 502-509. [In Russian].

Ianbay I. (2002). Marcel Perich's Poems. Rocz. Orientalistyczny. Vol. 55:2. Warszawa [b.v.], 5-4.

Ianbay I. (2017). Pesn' pesney tsarya Solomona i Targum na yazyke krymchakov. Iyerusalim [b.v.] [In Russian].

Ianbay I., Erdal M. (1998). The Krimchak translation of a targum seni of the Book of Ruth. Mediterranean Language Review. Vol. 10. Wiesbaden: Harrassowitz, 1-53.

Jankowski H. (1997). A Bible Translation into the Northern Crimean Dialect of Karaim. Studia Orientalia Electronica. Vol. 82. Helsinki [b.v.], 1-84.

Jankowski H. (2009). Two Crimean Karaim financial registers of the 18th century. Archivum Ottomanicum. Vol. 26. [b.m.] Harrassowitz, 17-40.

Jankowski H. (2010). Jezyk krymskotatarski. Warszawa: Dialog.

Jankowski H. (2013). Karaim mejumas in Eupatoria. Unknown Treasures of the Altaic World in Libraries, Archives and Museums. 53rd Annual Meeting of the Permanent International Altaistic Conference / Pang, S.-C. Raschmann, T.G. Winkelhane (Eds.). Berlin: Klaus Schwarz, 245-262.

Jankowski H. (2016). Karaim and Krymchak. Handbook of Jewish Languages / L. Khan, A. D. Rubin (Eds.). Leiden; Boston: Brill, 451-488.

Jankowski H. (2018). Krymchak language samples. Turkic Languages. Vol. 22(2). [b.m.] Harrassowitz, 276-294.

Kizilov M. (2008). Krymchaki: sovremennoye sostoyaniye obschiny. Yevroaziatskiy yevreyskiy yezhegodnik. Vol. 5768. Moscow: Pallada, 56-82. [In Russian].

Kizilov M. (2011). Krymskaya Iudeya: ocherki istorii yevreev, hazar, karaimov i krymchakov v Krymu s antichnyh vremen do nashikh dney. Simferopol: Dolya. [In Russian].

Kropotova N. (2014). Dzhonki i medzhuma v tyurkskoj kulture: literatura ili fol'klor. Skhidnyi svit. Vol. 1, 43-47. [In Russian].

Nemeth M. (2011). Unknown Lutsk Karaim Letters in Hebrew script (19th-20th Centuries). A Critical Edition: Vol. Studia Turcologica Cracoviensia 12. Krakow: Jagiellonian University.

Polinsky M. (1991). The Krymchaks: History and Texts. Ural-Altaic Yearbook . Vol. 63. Berlin-Bloomington: Eurolingua, 123-154.

Prik O. (1976). Ocherki grammatiki karaimskogo yazyka (krymskiy dialekt). Makhachkala: Daguchpedgiz. [In Russian].

Prokosch E. (2009). Tschagataische Grammatik unter Berücksichtigung des Substandarts. Vol. Grazer Linguistische Monographien 27. Graz [b.v.].

Radlov W. (1898). Obrazcy narodnoy literatury tureckih plemen (Narečiya Krymskogo poluostrova. Vol. 7. Saint Petersburg [b.v.]. [In Russian].

Rebi D. (2008). Krymchaksko-russkij slovar'. Simferopol: Dolia. [In Russian].

Rebi D. (2010). Pismennoye naslediye krymchakov. Simferopol: Dolia. [In Russian].

Rebi D., Lombrozo V. (2000). Krymchaki. Simferopol [b.v.]. [In Russian].

Szapszal S. (1916). Skazka na yazyke krymskih yevreev (krymchakov), zapisannaya v g. Karasubazare letom 1911 g. Zapiski Vostočnogo otdeleniya Russkogo akheologičeskogo obschestva. Vol. 23. Saint Petersburg [b.v.], iv-v. [In Russian].

Tyshchenko-Monastyrska O. (2016). Karaimska medzhuma z Bakhchysaraiskoho palatsu. Zagrozheni movy. Krymskotatarska ta inshi tyurkski movy v Ukrayini. Kyiv: In-t shodoznavstva im. A. Yu. Krymskoho, 239-254. [In Ukrainian].

Zieme P. (1991). Die Stabreimtexte der Uiguren von Turfan und Dunhuang. Studien zur Alttürkischen Dichtung. Budapest: Akademiai Kiado. 
O. O. TYSHCHENKO-MONASTYRSKA

O. O. Potebnia Institute of Linguistics of the NAS of Ukraine

Kyiv, Ukraine

E-mail: tyshchenko.monastyrska@gmail.com

https://orcid.org/0000-0001-8515-1657

\section{PECULIAR FEATURES OF THE KRYMCHAK DZHONK SCRIPT AND THE KRYMCHAK WRITTEN LANGUAGE TRADITION}

The subject of the present publication is to bring to the light some orthographic features of the Yosyf Gabai's Krymchak manuscript, called jonk, from Crimean Ethnographic Museum (Simferopol). Fragments of the manuscript were first transcribed, translated into Russian and published by David Rebi, who was a teacher of Krymchak and native speaker. However, the jonk has never been edited before. A special value of this manuscript lies in its language (or even languages), as well as styles represented. The manuscript is multilingual, contains folklore texts (poetry and narrative) of the Crimean and Turkish origin, written in Hebrew script, diary notes both in Krymchak and Russian, prayers and religion texts in Hebrew partially translated into Turkic written in the early XX century in Feodosia. This research is dedicated to Turkic linguistic features and their orthography. Despite of using Hebrew script Krymchak writing system developed in close relation to pre-reform Crimean Tatar writing tradition, both variants in their turn connected to Ottoman and pre-Ottoman orthographic traditions. Several orthographic features point to that, for instance principles of writing some vowels, consonants (in initial, central, final positions), grammatical and word-formation suffixes (connected or separate writing), morphonological change, ways of transcription and adopting loanwords. Language of Yosyf Gabai's jonk reflects orthographic and colloquial features of Krymchak and shares them with other Crimean Turkic manuscripts of this period. Schematically marked suffixes, together with some archaic morphonological changes, graphically reflected in the text, such as disrupted vowel harmony, alternations in labial harmony, syncope, epenthesis, protheses, disrupted consonant change between morphemes characterize orthography of the Krymchak manuscript.

Keywords: Krymchak Turkic language, Hebrew-Turkic orthography, separate suffix writing.

Дата надходження до редакції - 26.10.2020

Дата затвердження редакцією - 04.11.2020 